\title{
Loss of Muscarinic Autoreceptor Function Impairs Long- Term Depression But Not Long-Term Potentiation in the Striatum
}

\author{
Paola Bonsi, ${ }^{1}$ Giuseppina Martella, ${ }^{2}$ Dario Cuomo, ${ }^{2}$ Paola Platania, ${ }^{2}$ Giuseppe Sciamanna, ${ }^{1,2}$ Giorgio Bernardi, ${ }^{1,2}$ \\ Jürgen Wess, ${ }^{3}$ and Antonio Pisani ${ }^{1,2}$ \\ ${ }^{1}$ Fondazione Santa Lucia Instituto di Ricovero e Cura a Carattere Scientifico, Rome 00146, Italy, ${ }^{2}$ Department of Neuroscience, University "Tor Vergata," \\ Rome 00133, Italy, and ${ }^{3}$ Molecular Signaling Section, Laboratory of Bioorganic Chemistry, National Institute of Diabetes and Digestive and Kidney \\ Diseases, National Institutes of Health, Bethesda, Maryland 20892-0810
}

\begin{abstract}
Muscarinic autoreceptors regulate cholinergic tone in the striatum. We investigated the functional consequences of genetic deletion of striatal muscarinic autoreceptors by means of electrophysiological recordings from either medium spiny neurons (MSNs) or cholinergic interneurons (ChIs) in slices from single $\mathrm{M}_{4}$ or double $\mathrm{M}_{2} / \mathrm{M}_{4}$ muscarinic acetylcholine receptor (mAChR) knock-out ( $-/-$ ) mice. In control ChIs, the muscarinic agonist oxotremorine $(300 \mathrm{nM})$ produced a self-inhibitory outward current that was mostly reduced in $\mathrm{M}_{4}{ }^{-l-}$ and abolished in $\mathrm{M}_{2} / \mathrm{M}_{4}^{-l-}$ mice, suggesting an involvement of both $\mathrm{M}_{2}$ and $\mathrm{M}_{4}$ autoreceptors. In $\mathrm{MSNs}^{-}$from both $\mathrm{M}_{4}{ }^{-1-}$ and $\mathrm{M}_{2} / \mathrm{M}_{4}{ }^{-1-}$ mice, muscarine caused a membrane depolarization that was prevented by the $\mathrm{M}_{1}$ receptor-preferring antagonist pirenzepine $(100 \mathrm{nM})$, suggesting that $\mathrm{M}_{1}$ receptor function was unaltered. Acetylcholine has been involved in striatal long-term potentiation (LTP) or long-term depression (LTD) induction. Loss of muscarinic autoreceptor function is predicted to affect synaptic plasticity by modifying striatal cholinergic tone. Indeed, high-frequency stimulation of glutamatergic afferents failed to induce LTD in MSNs from both $\mathrm{M}_{4}{ }^{-1-}$ and $\mathrm{M}_{2} / \mathrm{M}_{4}{ }^{-I-}$ mice, as well as in wild-type mice pretreated with the $\mathrm{M}_{2} / \mathrm{M}_{4}$ antagonist AF-DX384 (11-[[2-[(diethylamino)methyl]-1piperidinyl]acetyl]-5,1 1-dihydro-6H-pyrido[2,3b][1,4] benzodiazepin-6-one). Interestingly, LTD could be restored by either pirenzepine (100 nM) or hemicholinium-3 (10 $\mu \mathrm{M})$, a depletor of endogenous ACh. Conversely, LTP induction did not show any difference among the three mouse strains and was prevented by pirenzepine. These results demonstrate that $\mathrm{M}_{2} / \mathrm{M}_{4}$ muscarinic autoreceptors regulate ACh release from striatal ChIs. As a consequence, endogenous ACh drives the polarity of bidirectional synaptic plasticity.
\end{abstract}

Key words: cholinergic interneuron; long-term depression; long-term potentiation; striatal slices; electrophysiology; muscarine

\section{Introduction}

Acetylcholine (ACh) plays an essential role in striatal synaptic plasticity and motor learning, as well as in the pathophysiology of movement disorders (Calabresi et al., 2000; Partridge et al., 2002; Pisani et al., 2007). Striatal ACh innervation is exclusively intrinsic, originating from large cholinergic interneurons (ChIs) (Bolam et al. 1984). Regardless of their paucity, cholinergic markers measured in this region are among the highest within the brain. ChIs exhibit autonomous pacemaker activity, firing action potentials at rest, providing a constant ACh tone in the striatum (Bennett and Wilson, 1999; Zhou et al., 2002). Maintenance of discrete ACh levels is ensured by either ACh degrading enzymes

Received Dec. 28, 2007; revised May 9, 2008; accepted May 12, 2008.

This work was supported by grants from the Bachmann-Strauss Dystonia and Parkinson's Foundation, Dystonia Medical Research Foundation (A.P.), Ministero Salute (Program Finalizzato and Articolo 56) (G.B., A.P.), Istituto Superiore Sanità (Malattie Rare) (A.P.), and Agenzia Spaziale Italiana (Disturbi del Controllo Motorio e Cardiorespiratorio grant) (A.P.). J.W. was supported by the Intramural Research Program of the National Institutes of Health, National Institute of Diabetes and Digestive and Kidney Diseases.

Correspondence should be addressed to Antonio Pisani, Department of Neuroscience, University of Rome "Tor Vergata," Via Montpellier 1, 00133 Rome, Italy. E-mail: pisani@uniroma2.it.

D0I:10.1523/JNEUROSCI.1678-08.2008

Copyright $\odot 2008$ Society for Neuroscience $\quad$ 0270-6474/08/286258-06\$15.00/0 or by $\mathrm{M}_{2} / \mathrm{M}_{4}$ muscarinic autoreceptors, which exert a negative feedback control on ACh release, hyperpolarizing ChIs through $\mathrm{Ca}_{\mathrm{v}} 2$ calcium current inhibition and the opening of potassium $\left(\mathrm{K}^{+}\right)$currents (Yan and Surmeier, 1996; Calabresi et al., 1998).

Five distinct muscarinic acetylcholine receptors (mAChRs; $\mathrm{M}_{1}-\mathrm{M}_{5}$ ) have been cloned and divided into two main classes, according to their pharmacological properties and transduction mechanisms (Wess et al., 2007). Receptor localization studies have revealed a predominant expression of $\mathrm{M}_{1}$ and $\mathrm{M}_{4}$ receptors on striatal neuronal subpopulations, whereas $\mathrm{M}_{2}$ and $\mathrm{M}_{3}$ are clearly less abundant (Zhang et al., 2002; Zhou et al., 2002). ACh also exerts its modulatory effects through nicotinic receptors, expressed on striatal dopaminergic terminals whose activation stimulates dopamine release. The close functional interplay between dopamine and nicotinic receptors is proven by the observation that nicotinic receptor antagonists prevent the induction of striatal synaptic plasticity (Partridge et al., 2002).

High-frequency stimulation (HFS) of the glutamatergic pathway causes either a long-lasting increase, or an enduring decrease in synaptic efficacy, referred to as long-term potentiation (LTP) or long-term depression (LTD), respectively (Calabresi et al., 1992a,b; Lovinger et al., 1993). Compelling evidence suggests that 
intrastriatal ACh levels dictate the polarity of plastic changes via $M_{1}$ receptor activation, that are expressed on dendrites and spines of medium spiny neurons (MSNs), and are therefore strategically positioned to influence synaptic plasticity (Hersch et al. 1994, Yan et al., 2001). Indeed, $M_{1}$ receptor activation increases MSN excitability by reducing KCNQ and Kir2 currents (Galarraga et al., 1999; Shen et al., 2005, 2007). Consequently, $M_{1}$ receptor activation favors MSN depolarization, playing a permissive role in LTP (Calabresi et al., 2000). However, $M_{1}$ receptor activation also inhibits $\mathrm{Ca}_{\mathrm{v}} 1$ and $\mathrm{Ca}_{\mathrm{v}} 2$ calcium currents (Howe and Surmeier, 1995) that are necessary for LTD induction. It has been proposed recently that reducing ambient $\mathrm{M}_{1}$ receptor stimulation promotes LTD through disinhibition of $\mathrm{Ca}_{\mathrm{v}} 1$ channels (Wang et al., 2006).

The lack of selective ligands for mAChRs has made it difficult to define the role of striatal mAChRs by pharmacological means (Wess et al., 2007). We analyzed the consequences of muscarinic autoreceptor loss on striatal synaptic plasticity by using a combined pharmacological/molecular genetic approach. Specifically, we performed electrophysiological recordings from MSNs and ChIs using slices from wild-type (WT), single $\mathrm{M}_{4}^{-1-}$, or double $\mathrm{M}_{2} / \mathrm{M}_{4}{ }^{-1-}$ mice (Gomeza et al., 1999a,b, 2001).

\section{Materials and Methods}

Slice preparation. All procedures were performed in accord with the European Commission guidelines (86/609/EEC) and approved by the University “Tor Vergata." Mice (4-6 weeks old) were generated as described (Gomeza et al., 1999a,b, 2001). WT littermates of the same mixed genetic background were used as controls. Coronal corticostriatal slices (180-250 $\mu \mathrm{m}$ ) were cut in Krebs' solution [containing (in mм) $126 \mathrm{NaCl}, 2.5 \mathrm{KCl}, 1.3 \mathrm{MgCl}_{2}, 1.2$ $\mathrm{NaH}_{2} \mathrm{PO}_{4}, 2.4 \mathrm{CaCl}_{2}, 10$ glucose, and 18 $\mathrm{NaHCO}_{3}$ ], bubbled with $95 \% \mathrm{O}_{2} /$ and $5 \% \mathrm{CO}_{2}$. Individual slices were transferred in a recording chamber $(\sim 0.5-1 \mathrm{ml}$ volume), continuously superfused with oxygenated Krebs' medium at $2.5-3 \mathrm{ml} / \mathrm{min}\left(32-33^{\circ} \mathrm{C}\right)$.

Electrophysiology. Current-clamp recordings were performed using sharp microelectrodes filled with $2 \mathrm{M} \mathrm{KCl}(40-60 \mathrm{M} \Omega)$. Signal acquisition and off-line analysis were performed using an Axoclamp 2B amplifier and pClamp9 software (Molecular Devices). Glutamatergic EPSPs were evoked with a bipolar electrode placed in the white matter. Test stimuli were delivered at $0.1 \mathrm{~Hz}$ in bicuculline. For highfrequency stimulation (three trains, $3 \mathrm{~s}$ duration, $100 \mathrm{~Hz}$ frequency, $20 \mathrm{~s}$ intervals), stimulus intensity was raised to suprathreshold levels. The amplitude of EPSPs was averaged and plotted as \% of the control amplitude for $\sim 10$ min before HFS. EPSPs did not reveal significant differences in the three groups of mice (data not shown) $(p>0.05)$ and were suppressed by the AMPA receptor antagonist CNQX (10 $\mu \mathrm{M})$.

Whole-cell recordings were made of ChIs visualized by means of infrareddifferential interference contrast videomicroscopy, as described (Bonsi et al.,
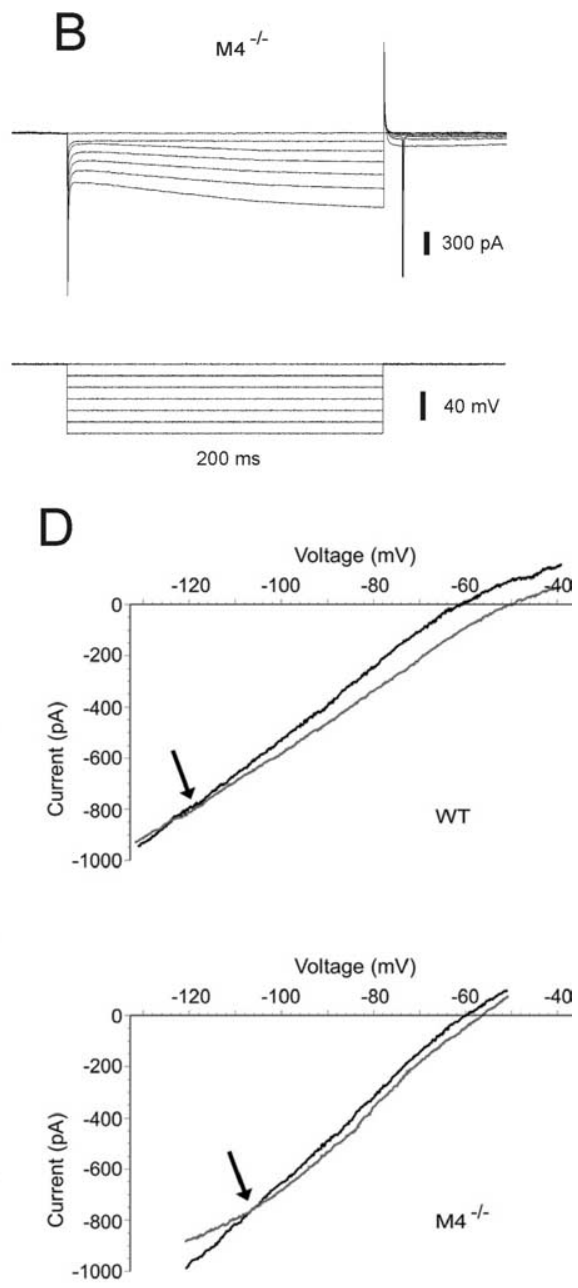

Figure 1. Muscarinic autoreceptor responses recorded from Chls of knock-out mice. $A$, Current-voltage relationships of Chls recorded in slices obtained from WT, $\mathrm{M}_{4}{ }^{-1-}$, and $\mathrm{M}_{2} / \mathrm{M}_{4}{ }^{-1-}$ mice are not significantly different from each other (ANOVA, $p>$ 0.05). $\boldsymbol{B}$, Representative recording of a $\mathrm{Chl}$ from $\mathrm{M}_{4}{ }^{-1-}$ mice showing no change in the typical sag caused by $I_{\mathrm{h}}$ activation at (botentials. C, Top, In a representative recording, bath application of oxotremorine (300 nM, $3 \mathrm{~min}$ ) induced an (gray trace; $300 \mathrm{~nm}$ ). Middle, The response to oxotremorine (black trace) is mostly reduced compared with WT, and was completely blocked by methoctramine in $\mathrm{M}_{4}{ }^{-1-}$ Chls (gray trace). Bottom, The recording shows the absence of any detectable response to bath-applied oxotremorine in $\mathrm{M}_{2} / \mathrm{M}_{4}{ }^{-1-}$ mice. The deflections represent voltage ramps applied before, at the peak of the oxotremorine-induced current, and after drug washout. D, Plots of a recording from a WT (top) and $\mathrm{M}_{4}{ }^{-1-} \mathrm{Chl}$ (bottom) showing the estimated reversal potential for the oxotremorine-induced current. Gray line, Voltage ramp in control condition; black line, voltage ramp at the peak of oxotremorine effect. Holding potential, $-60 \mathrm{mV}$. Error bars indicate SEM.

2007). Borosilicate glass pipettes (3-5 M 2 ) contained (in mM) $125 \mathrm{~K}^{+}$. gluconate, $10 \mathrm{NaCl}, 1 \mathrm{CaCl}_{2}, 2 \mathrm{MgCl}_{2}, 0.5$ BAPTA [1,2-bis (2aminophenoxy) ethane- $N, N, N, N$-tetraacetic acid], 19 HEPES, 0.3 GTP, and $1 \mathrm{Mg}$-ATP, adjusted to $\mathrm{pH} 7.3$ with $\mathrm{KOH}$. Membrane currents were monitored (Axopatch 200B; Molecular Devices) and access resistances measured in voltage clamp were in the range of 5-30 $\mathrm{M} \Omega$ before electronic compensation (60-80\% was routinely used). To compare correctly current-voltage relationships before and after drug perfusion, series resistances $(8-15 \mathrm{M} \Omega$ ) were monitored by the peak amplitude of the capacitive transient induced by a $-5 \mathrm{mV}$ step applied before a voltage ramp (from -120 to $-40 \mathrm{mV}, 6 \mathrm{mV} / \mathrm{s}$ ). Neurons in which series resistance changed by $>10 \%$ were discarded from the statistics. Values given are mean \pm SEM. Student's $t$ test and nonparametric Mann-Whitney tests were used to compare means before and after HFS/drug. ANOVA test and post hoc Tukey's test were performed among groups ( $p<0.05 ; \alpha=0.01)$. Drugs were from Tocris Cookson, except for muscarine, methoctramine, hemicholinium-3, and bicuculline (Sigma), and were applied by switching the control perfusion to drug-containing solution. 
A
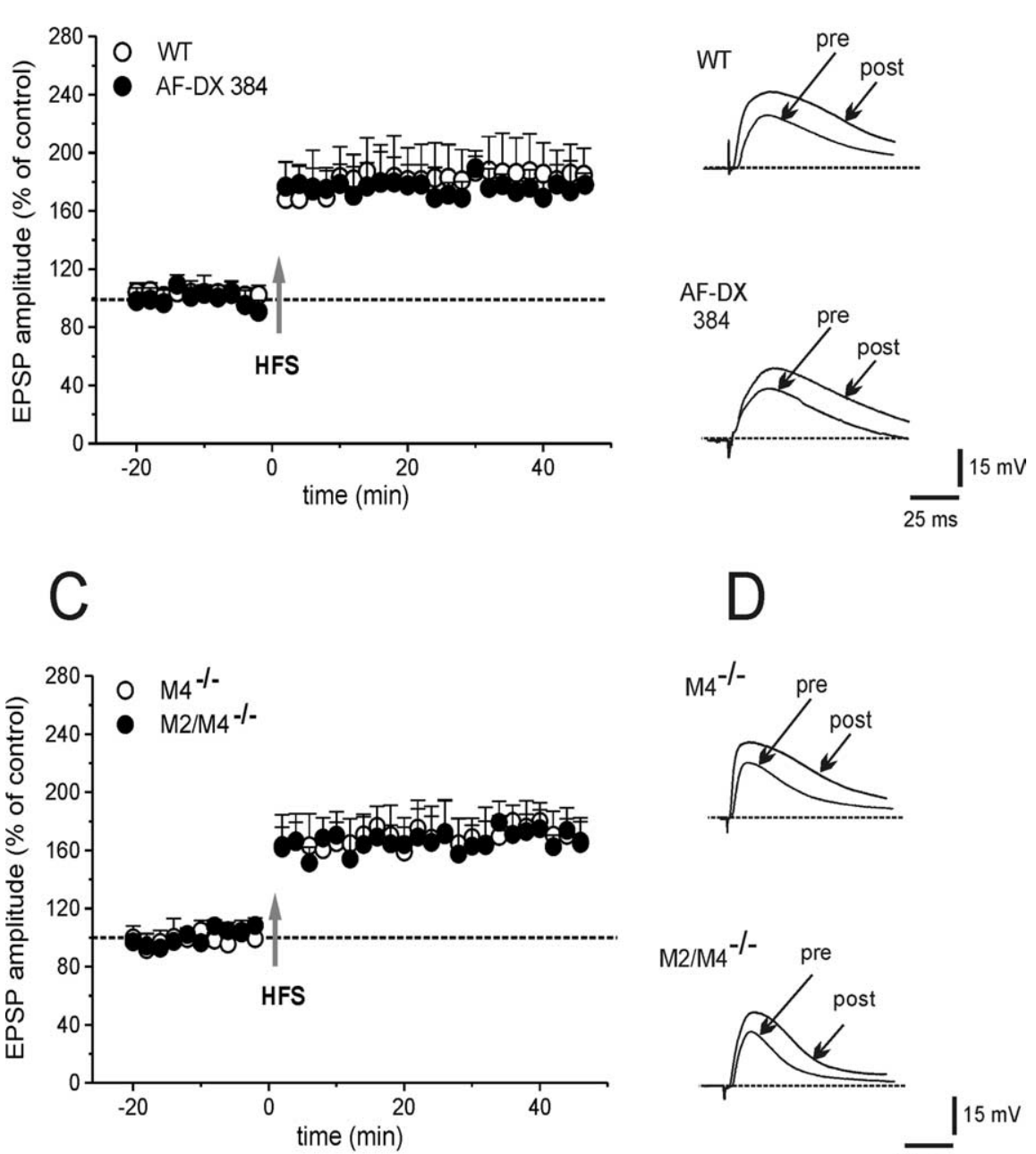

B
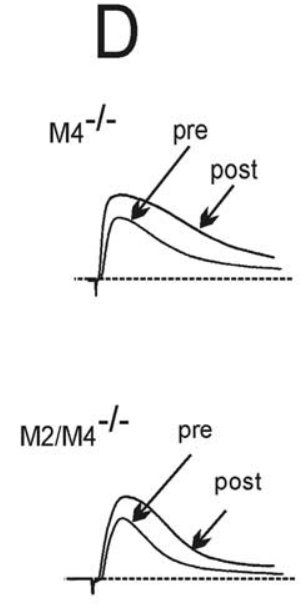

Figure 2. Normal LTP in mice lacking muscarinic autoreceptors. $\boldsymbol{A}$, Time course of changes in EPSP amplitude recorded from WT MSNs. In the absence of external magnesium (LTP induction protocol), HFS induced a marked potentiation of cortically evoked EPSP (open circles), which persisted for $>40$ min of recording. LTP was unaffected by $300 \mathrm{~nm}$ AF-DX384 in WT mice (filled circles). $B$, Representative traces of the EPSPs recorded before (pre) and 25 min after (post) HFS in WT (top) and in WT pretreated with AF-DX 384 (bottom). C, HFS induced a stable LTP in $\mathrm{M}_{4}{ }^{-1-}$ (open circles) as well as in $\mathrm{M}_{2} / \mathrm{M}_{4}{ }^{-1-}$ mice (filled circles). $\boldsymbol{D}$, The superimposed traces show the EPSP before (pre) and after (post) HFS in slices from $\mathrm{M}_{4}{ }^{-1-}$ and $\mathrm{M}_{2} / \mathrm{M}_{4}{ }^{-1-}$ mice. Each data point represents the mean \pm SEM.

\section{Results}

Loss of autoreceptor response in cholinergic interneurons

Large ChIs $(n=61)$ were identified by means of their peculiar electrophysiological properties (Kawaguchi, 1993; Bonsi et al., 2007). Intrinsic membrane properties were not significantly different among ChIs from WT mice and $\mathrm{M}_{4}{ }^{-1-}$ or $\mathrm{M}_{2} / \mathrm{M}_{4}{ }^{-1-}$ mice (ANOVA, $p>0.05$ ): these interneurons showed depolarized resting membrane potential (RMP; $\mathrm{WT},-56 \pm 1.3 \mathrm{mV}, n=10$; $\left.\mathrm{M}_{4}{ }^{-l-},-57 \pm 1.7 \mathrm{mV}, n=9 ; \mathrm{M}_{2} / \mathrm{M}_{4}{ }^{-/-},-53 \pm 4.7 \mathrm{mV}, n=6\right)$ and high input resistance (WT, $150 \pm 3.2 \mathrm{M} \Omega, n=10 ; \mathrm{M}^{-1-}$, $\left.144 \pm 3.9 \mathrm{M} \Omega, n=9 ; \mathrm{M}_{2} / \mathrm{M}_{4}{ }^{-l-}, 135 \pm 4.4 \mathrm{M} \Omega, n=6\right)$. More than half of the recorded cells exhibited a spontaneous firing activity. Hyperpolarizing current protocols activated a typical sag in the voltage response, indicative of an $I_{\mathrm{h}}$ current (Fig. $1 B$ ) whose amplitude (WT, $389.7 \pm 93.4 \mathrm{pA}, n=10 ; \mathrm{M}_{4}^{-/-}, 325.5 \pm$ $\left.78.0 \mathrm{pA}, n=9 ; \mathrm{M}_{2} / \mathrm{M}_{4}{ }^{-1-}, 300.3 \pm 41.3 \mathrm{pA}, n=6\right)$ and density $\left(\mathrm{WT}, 2.4 \pm 0.3 \mathrm{pA} / \mathrm{pF} ; \mathrm{M}_{4}^{-l-}, 2.7 \pm 0.2 \mathrm{pA} / \mathrm{pF} ; \mathrm{M}_{2} / \mathrm{M}_{4}{ }^{-l-}\right.$,

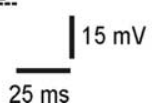

$2.8 \pm 0.4 \mathrm{pA} / \mathrm{pF})$ did not differ among the three strains (ANOVA, $p>0.05$ ). The current-voltage relationship did not show any significant change between ChIs from WT mice and $\mathrm{M}_{4}{ }^{-1-}$ or $\mathrm{M}_{2} / \mathrm{M}_{4}{ }^{-l-}$ mice (Fig. 1A).

It has been shown that activation of $\mathrm{M}_{2} / \mathrm{M}_{4}$ autoreceptors in ChIs generates a membrane hyperpolarization or an outward current (Calabresi et al., 1998; Pisani et al., 1999). In the presence of tetrodotoxin $(1 \mu \mathrm{M})$, oxotremorine $(300 \mathrm{nM}, 3$ min) induced an outward current in the recorded cells from WT mice (Fig. 1C) $(55 \pm 2.6 \mathrm{pA} ; n=7)$ coupled to a decreased conductance ( $81 \pm 3.2 \%$ of control; $n=7 ; p<0.05)$, which was blocked by incubation with the $\mathrm{M}_{2} / \mathrm{M}_{4}$ receptorpreferring antagonist methoctramine (300 $\mathrm{nm}, 10 \mathrm{~min}$ ). The reversal potential for this outward current was close to the calculated equilibrium potential for $\mathrm{K}^{+}$ions (Fig. $1 D)(-120 \pm 4.0 \mathrm{mV} ; n=6)$. Surprisingly, oxotremorine was still able to induce an outward current in $\mathrm{M}_{4}{ }^{-1-}$ mice (Fig. $1 C)(18 \pm 2.6 \mathrm{pA} ; n=7)$. This response was antagonized by methoctramine (Fig. $1 C$ ) and reversed at $-105 \pm 2.3$ $\mathrm{mV}$ (Fig. 1D). Conversely, the response to oxotremorine $(300 \mathrm{nM})$ was fully abolished in $\mathrm{M}_{2} / \mathrm{M}_{4}{ }^{-/-}$mice (Fig. 1C) $(n=4)$.

\section{Membrane and synaptic responses of MSNs}

MSNs from both WT and knock-out mice (WT, $n=24 ; \mathrm{M}_{4}{ }^{-l-}, n=36 ; \mathrm{M}_{2} / \mathrm{M}_{4}{ }^{-l-}$, $n=16)$ did not exhibit differences both of $\mathrm{RMP}$ (WT, $-89 \pm 6.1 \mathrm{mV}, n=19$; $\mathrm{M}_{4}^{-l-},-86 \pm 5.3 \mathrm{mV}, n=21 ; \mathrm{M}_{2} /$ $\mathrm{M}_{4}{ }^{-1-},-91 \pm 7.7 \mathrm{mV}, n=13$; ANOVA, $p>0.05)$ and input resistance (WT, $62.4 \pm 9.2 \mathrm{M} \Omega, n=19 ; \mathrm{M}^{-1-}, 59.6 \pm$ $10.6 \mathrm{M} \Omega, n=21 ; \mathrm{M}_{2} / \mathrm{M}_{4}^{-1-}, 61 \pm 8 \mathrm{M} \Omega$, $n=13$; ANOVA, $p>0.05$ ), as measured by means of intracellular recordings. Depolarizing current pulses showed membrane rectification and tonic action potential discharge. The current-voltage relationship did not show any change among groups.

$\mathrm{M}_{1}$ receptor activation has been shown to depolarize MSNs (Calabresi et al., 2000). Accordingly, perfusion of muscarine (30 $\mu \mathrm{M}, 1 \mathrm{~min})$ caused a reversible membrane depolarization of MSNs from WT $(5.6 \pm 3 \mathrm{mV} ; n=8)$ as well as from $\mathrm{M}_{4}{ }^{-1-}$ $(5.8 \pm 3.5 \mathrm{mV} ; n=6)$ and $\mathrm{M}_{2} / \mathrm{M}_{4}{ }^{-1-}(5.5 \pm 4 \mathrm{mV} ; n=5)$ mice that was prevented by the $M_{1}$ receptor-preferring antagonist pirenzepine (100 nM) (supplemental Fig. 1, available at www. jneurosci.org as supplemental material).

\section{Knock-out mice lacking striatal mAChRs retain LTP}

Removal of magnesium from the perfusing solution reveals an NMDA-mediated component of EPSPs and optimizes LTP induction (Calabresi et al., 1992b). Accordingly, HFS invariably induced LTP in MSNs from WT mice (Fig. $2 A, B)(180 \pm 28 \%$ of 
control, 25 min post-HFS; $n=7$; MannWhitney, $p=0.005)$. Moreover, blocking $\mathrm{M}_{1}$ receptors with $100 \mathrm{~nm}$ pirenzepine prevented LTP in WT MSNs (108 $\pm 8.8 \%$; $n=6 ; t$ test, $p=0.9$ ) (data not shown), confirming that $M_{1}$ receptors promote LTP. In $\mathrm{M}_{4}^{-1-}$ or $\mathrm{M}_{2} / \mathrm{M}_{4}^{-/-}$mice, HFS induced a LTP of a magnitude similar to that measured in WT littermates (Fig. $2 C, D)\left(\mathrm{M}_{4}{ }^{-l-}, 172 \pm 22 \%, n=7 ; \mathrm{M}_{2} /\right.$ $\mathrm{M}_{4}{ }^{-1-}, 164 \pm 17 \%, n=5$; ANOVA, $p>$ $0.05)$. In both knock-out strains, pretreatment with $100 \mathrm{nM}$ pirenzepine did not cause significant changes of basal EPSP, but prevented LTP (data not shown) $(n=$ 3). To verify these data pharmacologically, WT slices were incubated with the $\mathrm{M}_{2} / \mathrm{M}_{4}$ receptor antagonist 11-[[2-[(diethylamino)methyl]-1-piperidinyl]acetyl]-5,1 1-dihydro$6 H$-pyrido[2,3b] $[1,4]$ benzodiazepin-6one (AF-DX384; $300 \mathrm{~nm}, 20 \mathrm{~min}$ ). Under this experimental condition, no significant effect on control EPSP was recorded. Yet, LTP induction was not different from control LTP (Fig. 2A,B) (172.8 \pm 17.2\%; $n=6$; ANOVA, $p=0.2$ ). Therefore, either genetic or pharmacological blockade of striatal muscarinic autoreceptors failed to alter LTP.

In principle, blockade of LTP by pirenzepine could be a consequence of a facilitatory action on LTD. Thus, in a final set of experiments in $\mathrm{M}_{4}{ }^{-1-}$ mice, slices were treated with sulpiride to block LTD $(3 \mu \mathrm{M}$, $15 \mathrm{~min})$ and then pirenzepine was added (100 $\mathrm{nM}, 15 \mathrm{~min})$. In this experimental condition, HFS failed to induce LTP both in WT and $\mathrm{M}_{4}{ }^{-1-}$ mice $(110.6 \pm 13.7 \% ; n=6 ; t$ test, $p=0.38)$, confirming that M1 receptors are indeed necessary for LTP induction.

\section{Lack of LTD at glutamatergic synapses}

Ambient ACh concentrations exert a central role both in LTD or LTP. Loss of striatal muscarinic autoreceptor function is therefore expected to affect LTD by elevating cholinergic tone. HFS caused LTD in MSNs from WT mice (Fig. 3A,B) $(49.3 \pm 11 \%$ of control, measured 25 min post-HFS; $n=6$; $t$ test, $p<0.01)$. Conversely, in MSNs from $\mathrm{M}_{4}{ }^{-/-}$or $\mathrm{M}_{2} / \mathrm{M}_{4}{ }^{-/-}$mice, HFS failed to induce LTD (Fig. $3 A, B)\left(\mathrm{M}_{4}{ }^{-1-}, 100.3 \pm 8 \% ; \mathrm{M}_{2} / \mathrm{M}_{4}{ }^{-1-}\right.$, $96.6 \pm 8 \% ; n=6$ for each strain; $t$ test, $p=0.3)$. Moreover, in WT slices, pretreatment with the $\mathrm{M}_{2} / \mathrm{M}_{4}$ receptor antagonist, AFDX384 (300 nM, $20 \mathrm{~min}$ ), fully prevented LTD (data not shown) $(103 \pm 17 \% ; n=5, p=0.62)$, suggesting that either pharmacological blockade or genetic deletion of muscarinic autoreceptors impairs striatal LTD.

Assuming that this impairment was caused by an increase in striatal ACh release, lowering cholinergic tone is expected to restore LTD. Slices were bathed with hemicholinium-3 (10 $\mu \mathrm{M}, 20$ min), which depletes endogenous ACh (Parikh and Sarter, 2006). Hemicholinium-3 did not change EPSP amplitude per se, but completely rescued LTD in both $\mathrm{M}_{4}{ }^{-1-}$ and $\mathrm{M}_{2} / \mathrm{M}_{4}{ }^{-1-}$ mice (Fig. $3 C, D)\left(58.1 \pm 13.6 \%\right.$ and $53.2 \pm 9 \%$ of control; $n=6$ for $\mathrm{M}_{4}$ and $\mathrm{M}_{2} / \mathrm{M}_{4}$, respectively; $t$ test, $\left.p<0.001\right)$. Hemicholinium-3 did
B
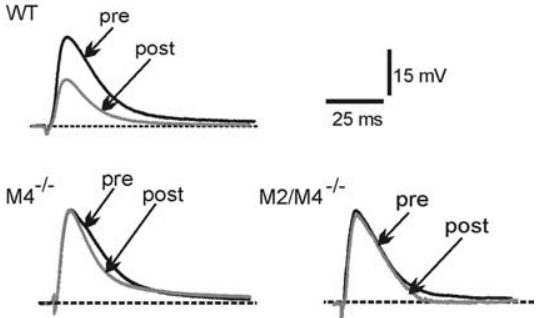

D
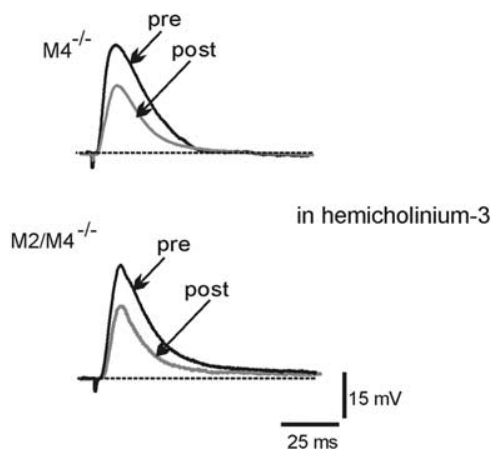

Figure 3. Impairment of striatal LTD. A, In MSNs from WT mice, HFS of glutamatergic fibers induced LTD of EPSPs $(+/+$, open circles, respectively) $B$ The superimposed traces represent the EPSPs recorded before (pre) and 25 min after (post) HFS in WT and knock-out mice. $C$, In slices incubated with hemicholinium-3 (300 nM), HFS restored LTD in $\mathrm{M}_{4}{ }^{-1-}$ and $\mathrm{M}_{2} / \mathrm{M}_{4}{ }^{-1-}$ mice (open before (pre) and after (post; $25 \mathrm{~min}$ ) HFS in slices from both $\mathrm{M}_{4}{ }^{-1-}$ and $\mathrm{M}_{2} / \mathrm{M}_{4}{ }^{-1-}$ mice in the presence of hemicholinium-3. Each data point represents the mean \pm SEM.

not cause any change in LTD in MSNs from WT mice (Fig. 3C) (58 $\pm 9 \% ; n=3 ; p=0.13)$.

To verify whether the impairment of LTD involved $M_{1}$ receptors, slices were treated with either the non-subtype-selective mAChRs antagonist scopolamine or with the $M_{1}$ receptorpreferring antagonist pirenzepine. Both $3 \mu \mathrm{M}$ scopolamine (20 min) and pirenzepine (100 nM, $20 \mathrm{~min})$ did not modify basal EPSP amplitude, but restored LTD (Fig. 4) (scopolamine: $67.3 \pm$ $11.3 \%, n=5$, Mann-Whitney, $p<0.0001$ for $\mathrm{M}_{4}{ }^{-1-}$ mice; $65 \pm$ $14.4 \%, n=5, p<0.0001$ for $\mathrm{M}_{2} / \mathrm{M}_{4}{ }^{-1-}$ mice; pirenzepine: $53 \pm 10.5 \%, n=6, t$ test $p<0.0001$ for $\mathrm{M}_{4}{ }^{-1-}$ mice; $51.4 \pm$ 9.5\%, $n=6, p<0.0001$ for $\mathrm{M}_{2} / \mathrm{M}_{4}{ }^{-1-}$ mice; ANOVA among groups, $p=0.7)$.

"Competition" between LTD and LTP could hypothetically account for the rescue of LTD by pirenzepine. To address this hypothesis, the effects of pirenzepine on LTD were tested also in the presence of MK-801 [(+)-5-methyl-10,11-dihydro-5Hdibenzo [a,d] cyclohepten-5,10-imine maleate; $30 \mu \mathrm{M}, 15 \mathrm{~min}$ ], an NMDA receptor antagonist, to block LTP. In such experimental condition, HFS was still able to restore LTD in $\mathrm{M}_{4}{ }^{-1-}$ mice (48.7 $\pm 11.6 \% ; n=5$; Mann-Whitney, $p<0.0001)$.

\section{Discussion}

Maintenance of ACh homeostasis in the striatum is of primary importance for correct motor control (Pisani et al., 2007). Loss of autoreceptors expressed on striatal ChIs is therefore expected to lead to a tonic increase in ACh levels and altered locomotion. 

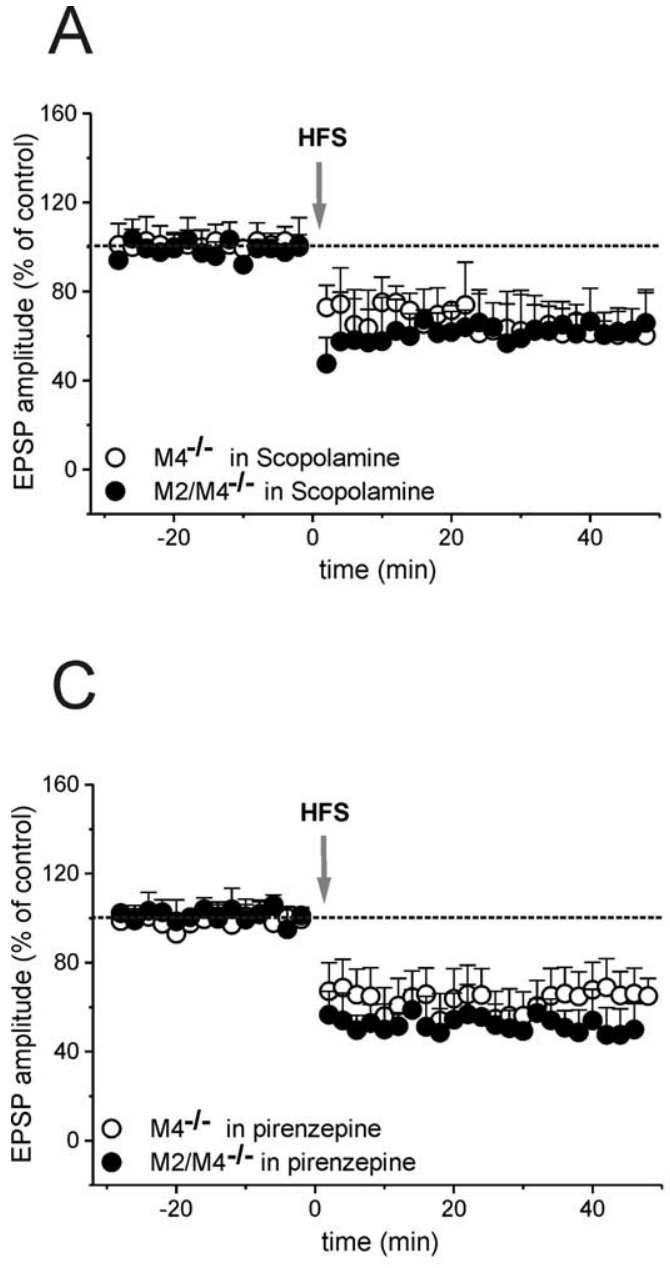
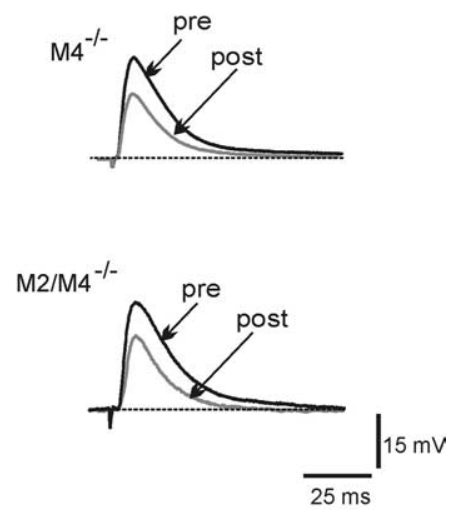

in pirenzepine
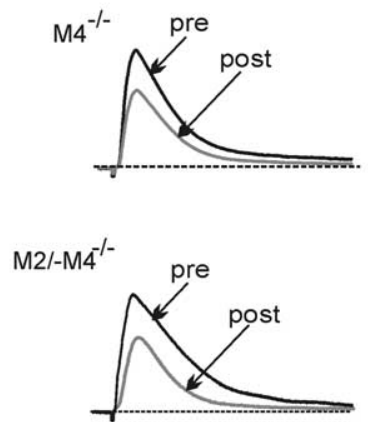

Figure 4. Blockade of $M_{1}$ muscarinic receptors restores LTD. $A$, EPSP amplitudes in MSNs from $M_{4}{ }^{-1-}$ (open circles) and $\mathrm{M}_{2} / \mathrm{M}_{4}{ }^{-1-}$ (filled circles) are plotted in the presence of scopolamine $(3 \mu \mathrm{M})$. $\boldsymbol{B}$, Representative traces of EPSP recorded before and $25 \mathrm{~min}$ after HFS in scopolamine from both groups of mice. C, Time course of EPSP amplitudes in pirenzepine (100 nm) in $\mathrm{M}_{4}{ }^{-1-}$ (open circles) and $\mathrm{M}_{2} / \mathrm{M}_{4}{ }^{-1-}$ (closed circles) mice. $\boldsymbol{D}$, Individual traces shown before (pre) and after (post) HFS. Data points are mean \pm SEM.

Indeed, the oxotremorine-mediated inhibition of $\mathrm{K}^{+}$-stimulated $\left[{ }^{3} \mathrm{ACh}\right.$ ] efflux was completely lost in cortical and striatal tissues from $\mathrm{M}_{2} / \mathrm{M}_{4}{ }^{-1-}$ mice (Zhang et al., 2002). Similarly, a large elevation in basal $\mathrm{ACh}$ content was found in the hippocampus of either $\mathrm{M}_{2}$ or $\mathrm{M}_{4}$ single or $\mathrm{M}_{2} / \mathrm{M}_{4}$ double knock-out mice (Tzavara et al., 2003). Moreover, in behavioral studies, $\mathrm{M}_{4}{ }^{-1-}$ mice displayed increased basal locomotor activity (Gomeza et al., 1999b).

Consistent with these findings, we found that the outward current recorded in ChIs was mostly reduced in single $\mathrm{M}_{4}{ }^{-1-}$ and abolished in $\mathrm{M}_{2} / \mathrm{M}_{4}{ }^{-1-}$ mice, implicating both receptors in the cholinergic autoreceptor response. Accordingly, anatomical and pharmacological evidence identified both the $\mathrm{M}_{2}$ and $\mathrm{M}_{4}$ subtypes as striatal autoreceptors (Zhang et al., 2002).

Disruption of the $\mathrm{M}_{2} / \mathrm{M}_{4}$-mediated autoregulatory mechanism has been shown to alter synaptic plasticity in the hippocampus as well as in the visual cortex (Tzavara et al., 2003; Origlia et al., 2006). We tested the hypothesis that a presumed increase in cholinergic tone would influence striatal synaptic plasticity, providing the first evidence that striatal synaptic plasticity is indeed critically dependent on the levels of endogenous $\mathrm{ACh}$, with

higher levels favoring LTP and lower levels promoting LTD. First, we found that MSNs from both $\mathrm{M}_{4}^{-l-}$ or $\mathrm{M}_{2} / \mathrm{M}_{4}{ }^{-1-}$ mice retain LTP. Second, pharmacological blockade of $\mathrm{M}_{2} / \mathrm{M}_{4}$ receptors with AFDX384 prevented LTD, but did not alter LTP induction in WT mice. Because ACh exerts its permissive role in LTP induction through $M_{1}$ receptor activation, we examined whether this pathway was preserved in MSNs of knock-out mice. In both $\mathrm{M}_{4}{ }^{-1-}$ and $\mathrm{M}_{2} / \mathrm{M}_{4}{ }^{-1-}$ mice, muscarine depolarized MSNs, confirming that M1 receptors were functional. In addition, LTP induction depended on $\mathrm{M}_{1}$ receptor activation in both knock-out mice, as it was fully prevented by pirenzepine.

Conversely, no striatal LTD was observed in either $\mathrm{M}_{4}^{-1-}$ or $\mathrm{M}_{2} / \mathrm{M}_{4}{ }^{-/-}$ mice. In keeping with the assumption that elevated striatal ACh release affected LTD in mice lacking muscarinic autoreceptors, we were able to restore LTD by lowering striatal cholinergic tone with hemicholinium-3, which blocks the highaffinity choline transporters, preventing ACh resynthesis (Parikh and Sarter, 2006). Reducing $M_{1}$ receptor activity has been proposed to facilitate LTD induction (Wang et al., 2006). Accordingly, we found that blockade of $M_{1}$ receptors with pirenzepine was able to fully rescue LTD in both $\mathrm{M}_{4}^{-l-}$ and $\mathrm{M}_{2} / \mathrm{M}_{4}{ }^{-/-}$mice.

Our data are consistent with the novel concept that bidirectional synaptic plasticity in the striatum is strictly regulated by ACh provided by ChIs. Under physiological conditions, striatal dopamine inhibits the activity of ChIs and ACh release (DeBoer et al., 1996; Pisani et al., 2000; Maurice et al., 2004). Moreover, different pathophysiological conditions characterized by striatal dopaminergic dysfunction, including Parkinson's disease and dystonia, are accompanied by abnormal cholinergic function (Ding et al., 2006; Pisani et al., 2007). Accordingly, $\mathrm{mAChRs}$ antagonists are used in the symptomatic treatment of these movement disorders (Lang and Lees, 2002; Horn and Comella, 2007). The findings reported here may contribute to a better understanding of how alterations in striatal circuitry are linked to motor dysfunction and eventually help identify novel therapeutic strategies to fine tune striatal cholinergic function in human disease.

\section{References}

Bennett BD, Wilson CJ (1999) Spontaneous activity of neostriatal cholinergic interneurons in vitro. J Neurosci 19:5586-5596.

Bolam JP, Wainer BH, Smith AD (1984) Characterization of cholinergic interneurons in the rat neostriatum. A combination of choline acetyltransferase immunocytochemistry, Golgi-impregnation and electron microscopy. Neuroscience 12:711-718.

Bonsi P, Cuomo D, Ding J, Sciamanna G, Ulrich S, Tscherter A, Bernardi G, Surmeier DJ, Pisani A (2007) Endogenous serotonin excites striatal cholinergic interneurons via the activation of 5-HT 2C, 5-HT6, and 5-HT7 
serotonin receptors: implications for extrapyramidal side effects of serotonin reuptake inhibitors. Neuropsychopharmacology 32:1840-1854.

Calabresi P, Maj R, Pisani A, Mercuri NB, Bernardi G (1992a) Long-term synaptic depression in the striatum: physiological and pharmacological characterization. J Neurosci 12:4224-4233.

Calabresi P, Pisani A, Mercuri NB, Bernardi G (1992b) Long-term potentiation in the striatum is unmasked by removing the voltage-dependent magnesium block of NMDA receptor channels. Eur J Neurosci 4:929-935.

Calabresi P, Centonze D, Pisani A, Sancesario G, North RA, Bernardi G (1998) Muscarinic IPSPs in rat striatal cholinergic interneurones. J Physiol (Lond) 510:421-427.

Calabresi P, Centonze D, Gubellini P, Pisani A, Bernardi G (2000) Acetylcholine-mediated modulation of striatal function. Trends Neurosci 23:120-126.

DeBoer P, Heeringa MJ, Abercrombie ED (1996) Spontaneous release of acetylcholine in striatum is preferentially regulated by inhibitory dopamine D2 receptors. Eur J Pharmacol 317:257-262.

Ding J, Guzman JN, Tkatch T, Chen S, Goldberg JA, Ebert PJ, Levitt P, Wilson CJ, Hamm HE, Surmeier DJ (2006) RGS4-dependent attenuation of M4 autoreceptor function in striatal cholinergic interneurons following dopamine depletion. Nat Neurosci 9:832-842.

Galarraga E, Hernández-López S, Reyes A, Miranda I, Bermudez-Rattoni F, Vilchis C, Bargas J (1999) Cholinergic modulation of neostriatal output: a functional antagonism between different types of muscarinic receptors. J Neurosci 19:3629-3638.

Gomeza J, Shannon H, Kostenis E, Felder C, Zhang L, Brodkin J, Grinberg A, Sheng H, Wess J (1999a) Pronounced pharmacologic deficits in M2 muscarinic acetylcholine receptor knock-out mice. Proc Natl Acad Sci USA 96:1692-1697.

Gomeza J, Zhang L, Kostenis E, Felder C, Bymaster F, Brodkin J, Shannon H, Xia B, Deng C, Wess J (1999b) Enhancement of D1 dopamine receptormediated locomotor stimulation in $\mathrm{M}_{4}$ muscarinic acetylcholine receptor knock-out mice. Proc Natl Acad Sci USA 96:10483-10488.

Gomeza J, Zhang L, Kostenis E, Felder CC, Bymaster FP, Brodkin J, Shannon H, Xia B, Duttaroy A, Deng CX, Wess J (2001) Generation and pharmacological analysis of M2 and M4 muscarinic receptor knock-out mice. Life Sci 68:2457-2466.

Hersch SM, Gutekunst CA, Rees HD, Heilman CJ, Levey AI (1994) Distribution of $\mathrm{m} 1-\mathrm{m} 4$ muscarinic receptor proteins in the rat striatum: light and electron microscopic immunocytochemistry using subtype-specific antibodies. J Neurosci 14:3351-3363.

Horn S, Comella CL (2007) Treatment of dystonia. In: Parkinson's disease and movement disorders, Ed 5 (Jankovic J, Tolosa E, eds), pp 348-355. Philadelphia: Lippincott Williams and Wilkins.

Howe AR, Surmeier DJ (1995) Muscarinic receptors modulate N-, P-, and L-type $\mathrm{Ca}^{2+}$ currents in rat striatal neurons through parallel pathways. J Neurosci 15:458-469.

Kawaguchi Y (1993) Physiological, morphological, and histochemical characterization of three classes of interneurons in rat neostriatum. J Neurosci 13:4908-4923.

Lang AE, Lees A (2002) Anticholinergic therapies in the treatment of Parkinson's disease. In: Management of Parkinson's disease: an evidencebased review. Mov Disord 17 [Suppl] 4:S7-S12.

Lovinger DM, Tyler EC, Merritt A (1993) Short- and long-term synaptic depression in rat neostriatum. J Neurophysiol 70:1937-1949.
Maurice N, Mercer J, Chan CS, Hernandez-Lopez S, Held J, Tkatch T, Surmeier DJ (2004) D2 dopamine receptor-mediated modulation of voltage-dependent $\mathrm{Na}+$ channels reduces autonomous activity in striatal cholinergic interneurons. J Neurosci 24:10289-10301.

Origlia N, Kuczewski N, Aztiria E, Gautam D, Wess J, Domenici L (2006) Muscarinic acetylcholine receptor knock-out mice show distinct synaptic plasticity impairments in the visual cortex. J Physiol 577:829-840.

Parikh V, Sarter M (2006) Cortical choline transporter function measured in vivo using choline-sensitive microelectrodes: clearance of endogenous and exogenous choline and effects of removal of cholinergic terminals. J Neurochem 97:488-503.

Partridge JG, Apparsundaram S, Gerhardt GA, Ronesi J, Lovinger DM (2002) Nicotinic acetylcholine receptors interact with dopamine in induction of striatal long-term depression. J Neurosci 22:2541-2549.

Pisani A, Calabresi P, Centonze D, Marfia GA, Bernardi G (1999) Electrophysiological recordings and calcium measurements in striatal large aspiny interneurons in response to combined $\mathrm{O} 2 /$ glucose deprivation. J Neurophysiol 81:2508-2516.

Pisani A, Bonsi P, Centonze D, Calabresi P, Bernardi G (2000) Activation of D2-like dopamine receptors reduces synaptic inputs to striatal cholinergic interneurons. J Neurosci 20:RC69.

Pisani A, Bernardi G, Ding J, Surmeier DJ (2007) Re-emergence of striatal cholinergic interneurons in movement disorders. Trends Neurosci 30:545-553.

Shen W, Hamilton SE, Nathanson NM, Surmeier DJ (2005) Cholinergic suppression of KCNQ channel currents enhances excitability of striatal medium spiny neurons. J Neurosci 25:7449-7458.

Shen W, Tian X, Day M, Ulrich S, Tkatch T, Nathanson NM, Surmeier DJ (2007) Cholinergic modulation of Kir2 channels selectively elevates dendritic excitability in striatopallidal neurons. Nat Neurosci 10:1458-1466.

Tzavara ET, Bymaster FP, Felder CC, Wade M, Gomeza J, Wess J, McKinzie DL, Nomikos GG (2003) Dysregulated hippocampal acetylcholine neurotransmission and impaired cognition in M2, M4 and M2/M4 muscarinic receptor knock-out mice. Mol Psych 8:673-679.

Wang Z, Kai L, Day M, Ronesi J, Yin HH, Ding J, Tkatch T, Lovinger DM, Surmeier DJ (2006) Dopaminergic control of corticostriatal long-term synaptic depression in medium spiny neurons is mediated by cholinergic interneurons. Neuron 50:443-452.

Wess J, Eglen RM, Gautam D (2007) Muscarinic acetylcholine receptors: mutant mice provide new insights for drug development. Nat Rev Drug Discov 6:721-733.

Yan Z, Surmeier DJ (1996) Muscarinic (m2/m4) receptors reduce N- and P-type $\mathrm{Ca}^{2+}$ currents in rat neostriatal cholinergic interneurons through a fast, membrane-delimited, G-protein pathway. J Neurosci 16:2592-2604.

Yan Z, Flores-Hernandez J, Surmeier DJ (2001) Coordinated expression of muscarinic receptor messenger RNAs in striatal medium spiny neurons. Neuroscience 103:1017-1024.

Zhang W, Basile AS, Gomeza J, Volpicelli LA, Levey AI, Wess J (2002) Characterization of central inhibitory muscarinic autoreceptors by the use of muscarinic acetylcholine receptor knock-out mice. J Neurosci 22:1709-1717.

Zhou FM, Wilson CJ, Dani JA (2002) Cholinergic interneuron characteristics and nicotinic properties in the striatum. J Neurobiol 53:590-605. 